Ambient Science, 2020: Vol. 07(Sp1); 14-19

DOI:10.21276/ambi.2020.07.sp1.ta01

\title{
The Indicator of Turkey's Appearance: a Relation Between Physical Education and Sport as per PISA-2015 Research Data
}

\author{
Isikgöz M. Enes', Sahin, H. Murat², Sahin, \\ Figen $^{2}$ \\ ${ }^{1}$ High School of Physical Education and Sports, Mardin Artuklu \\ University Mardin/ Turkey \\ ${ }^{2}$ Department of Sport Sciences, Aydin Adnan Menderes \\ University Aydin/Turkey \\ Study Area: Mardin, Turkey \& Aydin, Turkey \\ Coordinates: $37^{\circ} 18^{\prime} 46.4^{\prime \prime} \mathrm{N} ; 40^{\circ} 44^{\prime} 01.7^{\prime \prime E ~ \& ~}$ \\ $37^{\circ} 50^{\prime} 32.5824^{\prime \prime}-27^{\circ} 50^{\prime} 56.9724^{\prime \prime}$
}

Key words: Physical activity, OECD

\section{Abstract}

An attempt to describe OECD's data on physical education, sports, and physical activity in the PISA 2015 study was made within Turkey and the OECD average. The document analysis technique was used in the study. In this context, the data of the study were obtained from the tables in the third report of the OECD's research entitled "Student welfare," which was conducted with the participation of 540 thousand students in 72 countries, including 35 member and 37 partner countries, based on the PISA 2015 exam. The following results were achieved in the study: It was observed that the participation rate of students of the 15 age group in Turkey in the weekly physical education lesson at school and the average of students who did exercise or sports before school were above the OECD average and that the average of students who did exercise or sports after school was below the OECD average. According to the results, it was observed that their socio-economic prof ile did not change students' life satisfaction. Non participats in physical activities exhibited lower bullying levels. Participation or nonparticipation in physical activities did not affect students' sense of belonging to the school in Turkey.

have no right to vote (http://www.oecd.org/about/).

The OECD aims to support the governments of the member countries in maintaining financial stability, help them achieve sustainable economic growth, increase employment and high living standards, and contribute to the world economy's development. The OECD's main fields of work are development and economic reforms, but its work fields have diversified over time. The OECD has turned into a "standard-setting" organization in many areas such as education, population aging, retirement and insurance systems, employment, migration, health, environment and energy, climate change, the transition to low-carbon economies, sustainable development and development assistance. Although the OECD's recommendations and acceptable practices are not binding, the peer pressure resulting from the common understanding has a supportive function in member countries' reform processes and makes them essential (http://oecd.dt.mfa.gov.tr/Mission/). In this context, there are directorates in various fields (Economy, Environment, Employment, Labor and Social Affairs, Development, Public Administration, Education, and Skills, etc.) within the OECD (https://www.oecd.org/about/ document/list-

*Corresponding Author: pdgenes@artuklu.edu.tr, 
of. -departments-and-special-bodies.htm).

The Education and Skills Directorate (EDU) helps member countries provide quality education opportunities to contribute to personal development, sustainable economic growth, and social cohesion, and support member countries in creating and implementing effective policies to deal with the problems faced by their education systems. The Directorate regularly examines the education systems of member and non-member countries through peer reviews. Advances in education and practice systems, statistical data are collected in an annual publication called "Education at a Glance." While the Directorate's "International Student Assessment Program (PISA)" makes a direct assessment of the achievement levels of 15-year-old students every three years, in the "Education Policies Committee (EDPC)" studies are conducted to formulate and guide effective policies to solve the problems encountered in education systems. The examination of long-term trends and innovations in education is under the responsibility of the "Education Innovation and Research Center (CERI)." The projects "The Teaching and Learning International Survey (TALIS)" and "The Program for the International Assessment of Adult Competencies (PIAAC)" also aim to measure teachers' professional skills and adults' post-school skills, based on PISA tests (http:// OECD.dt.mfa.gov.tr/Mission/ShowInfoNote/355233).

As a member country, Turkey's National Education Ministry (MoNE) takes part in many programs such as EDPC, CERI, PISA, and TALIS carried out by the Directorate in order to closely follow the changes in the field of education in the world and to reflect these changes in our education system. Since 2000 , our country has been participating in the PISA survey, which has been conducted regularly every three years for 15 -year-old students whose target audience is enrolled in formal education in the seventh grade and above. PISA studies focus on one of the fields of reading, mathematics, and science, respectively, every three years, and mathematics in the 2003 PISA study, and science in the PISA study in 2006. Within the scope of PISA 2009, it was aimed to investigate reading skills performance and characteristics of school systems, effective learning environments in reading instruction, school effectiveness, education, and training leadership and productivity (https://abdigm.meb.gov.tr/www /oecd/icerik/478).

Besides the national evaluation studies in education, the education indicators are needed to determine our position at the international level in our globalizing world. For this reason, it is our country's level determination in the field of education, the deficiencies to be eliminated, and the measures to be taken, according to specific reference points. As an OECD member, our country participates in this research to raise the level of education. In the PISA research, data on students' motivations, opinions about themselves, psychological characteristics of learning processes, school environments, and families are collected with contextual questionnaires applied together with the main areas. These data are used in the interpretation of the data obtained in the cognitive field. Surveys are an essential part of PISA and provide valuable information that enables the improvement of test results. All countries participate in student and school surveys in PISA. Participating in other surveys (teacher survey, information and communication technologies survey, education career survey, and parent survey) is up to countries' choice. In the PISA 2015 survey application, Turkey just (MEB, 2020).

The Education and Skills Directorate analyzes the data collected through its programs and presents them as statistical information. Especially in the annual "Education at a Glance" reports, the fundamental indicators of how countries' education systems function are included under headings such as learning environments and schools, outputs of educational processes, access to education, financial resources allocated to education (https://stats.oecd. organ/). On the other hand, in the reports prepared by the OECD on PISA student performance, data are presented by comparing students' academic performance ( 15 age group) in a series of headings among countries. The aim here is to inform educators and policymakers about the quality of learning outcomes and equality of opportunity practices, especially with PISA results. In this context, the five-volume "PISA 2015 Results" research presented by OECD in 2017 within the scope of the sixth round of PISA provides essential data. Especially in the third volume of this research titled "The Welfare of Students," there are many remarkable research findings regarding the education-training processes associated with the PISA-2015 results. For example, comprehensive findings are given based on countries covering the relationship between negative (anxiety, fear of failure, economic reasons, etc.) and positive (interest, participation in the lesson, motivation to succeed, etc.) impulses in students' performance (OECD, 2017). International comparisons made in education are of great importance in bringing new perspectives to change the country's education systems, providing dynamism, and offering new ideas to researchers, educators, and politicians (Aydin et al., 2018). Learning whether the education system components play a significant role in developing the human resources needed in developing countries, achieve the desired results, and carry out development activities necessitate ongoing evaluation studies in this field (Atik, 2017). In this study, the general appearance of Turkey in OECD under the title of physical education lesson, sport and physical activity in "welfare of the students" in the third volume titled "The Welfare of Students" in the five-volume study of PISA 2015 Results published by the OECD in 2017 (OECD, 2017). When the literature is examined, studies on OECD's 
education and training indicators mostly focused on PISA. In these studies (Aydin et al., 2018; Aytekin \& Tertemiz, 2018; Dös and Atalmis, 2016; Erdem and Tat, 2019; Erdogan \& Güvendir, 2019; Iseri, 2019; Kiliçaslan \& Yavuz, 2019; Suna et al., 2020; Saban, 2019; Topçu \& Durak, 2019; Yildirim, 2012), it is seen that subjects such as evaluation of PISA results, comparison of PISA results from every year, educational resources and expenditures with PISA results, their relationship with the curriculum, course exam questions and teacher training, adequacy of textbooks, use of technology are examined. There is no study conducted on physical education and sports except for the Özkan (2020) titled the effect of students' participation in extracurricular activities on their academic success according to PISA-2015 data and Duran (2019) comparison of the curriculums and enrollment examinations for the departments of physical education and sports teacher education departments in Turkey and Finland. At this point, it is thought that this study will contribute to the literature. This study aimed to examine the general view of Turkey's indicators related to physical education and sports in OECD countries, according to the PISA 2015 study. In this context, an attempt to describe OECD's data on physical education, sports, and physical activity in the PISA 2015 study was made within Turkey and the OECD average. This study is limited to data reported for 15 -yr's students in 7 th grade and over in Turkey.

\section{Methodology:}

This study is designed in a descriptive general survey model. Its aim was to examine the general view of Turkey's indicators related to $\mathrm{PE}$ in OECD countries, according to the PISA 2015 study. Survey researches are research models that aim to describe a past or present situation in its current form (Karasar, 2014). A document analysis technique was used in the study. In this context, the data of the study were obtained from the tables in the third report of the OECD's research titled "Student welfare" (OECD, 2017) conducted with the participation of 540 thousand students in 72 countries, 35 members and 37 partner countries, based on the PISA-2o15 exam (https://www.oecdilibrary.org/education). The PISA study's target audience is 15 -year-old students enrolled in formal education in 7 th grade and above. In the PISA research, data on students' motivations, opinions about themselves, psychological characteristics of learning processes, school environments, and families are collected through contextual questionnaires applied together with the main areas. All countries participate in student and school surveys in PISA. Participating in other surveys (teacher survey, information and communication technologies survey, education career survey, and parent survey) is up to countries' choice. Turkey, in the PISA 2015 survey application, just joined the school and students. After the 15-minute break given after the PISA-2015 achievement test sessions, the students answered questionnaire, which took approximately 35 minutes.
According to Statistical Territorial Units Classification (STUC) level 1 in Turkey in the PISA-2015 application, 187 schools and 5895 students from 61 provinces representing 12 regions attended (MEB, 2016).

Table-1: Distribution of schools and students participated in PISA-215 from Turkey according to STUC

\begin{tabular}{llll}
\hline Region Code & Region name & $\mathrm{n}$ & $\%$ \\
\hline TR1 & Istanbul & 1070 & 18,15 \\
TR2 & West Marmara & 245 & 4,16 \\
$\mathrm{TR}_{3}$ & Aegean & 707 & 11,99 \\
$\mathrm{TR}_{4}$ & Eastern Marmara & 510 & 8,65 \\
$\mathrm{TR} 5$ & West Anatolia & 553 & 9,38 \\
$\mathrm{TR} 6$ & Mediterranean & 817 & 13,86 \\
TR7 & Middle Anatolia & 334 & 5,67 \\
TR8 & West Black Sea & 303 & 5,14 \\
TR9 & East Black Sea & 194 & 3,29 \\
TRA & Northeast Anatolia & 199 & 3,38 \\
TRB & Middle East Anatolia & 276 & 4,68 \\
TRC & Southeastern Anatolia & 687 & 11,65 \\
\multicolumn{1}{c}{ TOTAL } & & 5895 & 100,00 \\
\hline
\end{tabular}

The data were tabulated based on average scores for Turkey and OECD with descriptive statistical methods

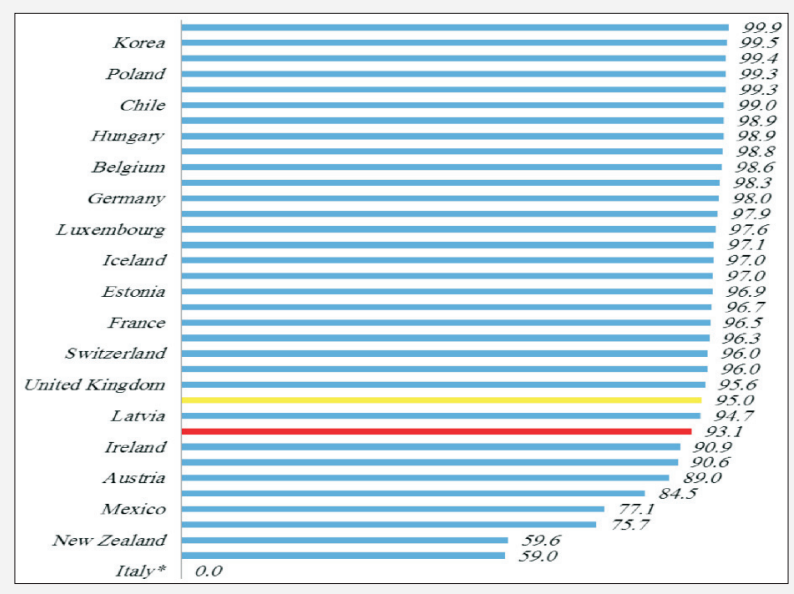

Figure-: Percentage of students attending weekly PE classes in OECD countrie

Table-1: Students' distribution participation before \& after school

\begin{tabular}{llllll}
\hline & Turkey & \multicolumn{2}{c}{ OECD Ort. } & \multicolumn{2}{c}{ Turkey OECD } \\
& $\%$ & SH & $\%$ & SH & Rank \\
\hline Before school & 61.0 & 0.9 & 43.0 & 0.1 & 2 \\
After school & 63.4 & 1.0 & 66.2 & 0.1 & 24 \\
Before and after school & 70.7 & 0.9 & 69.8 & 0.1 & 20 \\
\hline
\end{tabular}

As per table 3, Turkey is in the second place in participation before school; 24 th place in participation after school; twentieth place in participation before and after school among the 35 OECD countries.

According to table 4. Turkey is in the eleventh place in males participatants after school; thirtieth place in females participatants after school; second place in terms of the difference between males and females among the 35 OECD countries. 
Table 2. Distribution of participants in PE classes at school in terms of days per week (\%)

\begin{tabular}{|c|c|c|c|c|c|c|c|c|c|c|c|c|c|c|c|}
\hline & \multicolumn{2}{|c|}{$\mathrm{O}$} & \multicolumn{2}{|c|}{1} & \multicolumn{2}{|c|}{2} & \multicolumn{2}{|l|}{3} & \multicolumn{2}{|c|}{4} & \multirow[b]{2}{*}{$\%$} & \multicolumn{2}{|c|}{6 or 7 days } & \multicolumn{2}{|c|}{ Total Participation } \\
\hline & $\%$ & $\mathrm{SH}$ & $\%$ & $\mathrm{SH}$ & $\%$ & $\mathrm{SH}$ & $\%$ & $\mathrm{SH}$ & $\%$ & $\mathrm{SH}$ & & $\mathrm{SH}$ & $\%$ & $\mathrm{SH}$ & $\%$ \\
\hline Turkey & 5.0 & (1.4) & 46.6 & (1.7) & 23.7 & (1.3) & 2.4 & $(0.2)$ & 4.1 & $(0.5)$ & 18.3 & (o.9) & 0.0 & C & 95.0 \\
\hline OECD Ort. & 6.9 & (o.1) & 30.8 & $(0.3)$ & 39.4 & $(0.3)$ & 10.1 & $(0.2)$ & $4 \cdot 7$ & (o.1) & 6.6 & $(0.1)$ & 1.4 & (o.o) & 93.1 \\
\hline
\end{tabular}

Table-4: Participants' distrıbutıon after school by gendervariable

\begin{tabular}{|c|c|c|c|c|c|c|c|c|}
\hline & \multicolumn{2}{|l|}{ Male } & \multirow[t]{2}{*}{$\mathrm{R}$} & \multicolumn{2}{|l|}{ Female } & \multirow[t]{2}{*}{$\mathrm{R}$} & Gender Diff. $\mathrm{R}$ & $\mathrm{R}$ \\
\hline & $\%$ & SH & & $\%$ & $\mathrm{SH}$ & & $\% \quad \mathrm{SH}$ & \\
\hline $\begin{array}{l}\text { Turkey } \\
\text { OECD Ort. }\end{array}$ & $\begin{array}{l}76.4 \\
72.3\end{array}$ & (1.0) & 11 & $\begin{array}{l}50.7 \\
60.1\end{array}$ & (1.3) & & $\begin{array}{c}25.6 \\
\text { Rank) }\end{array}$ & 2 \\
\hline
\end{tabular}

Table-5: Students' distribution who engage in moderate and intensive physical activity outside of school

\begin{tabular}{|c|c|c|c|c|c|c|}
\hline Activity level & $\mathrm{W} / \mathrm{D}$ & Turk & & $\mathrm{OECl}$ & & Turkey's \\
\hline & & $\%$ & $\mathrm{SH}$ & $\begin{array}{l}\text { Av. } \\
\%\end{array}$ & $\mathrm{SH}$ & Rank \\
\hline Moderate & o & 17.8 & (o.6) & 10.9 & (o.1) & 4 \\
\hline & 1 & 19.7 & (o.6) & 11.3 & (o.1) & 1 \\
\hline & 2 & 15.7 & (o.6) & 12.6 & (o.1) & 6 \\
\hline & 3 & 10.8 & $(0.5)$ & 11.9 & (o.1) & 24 \\
\hline & 4 & 6.1 & $(0.4)$ & 8.4 & (o.1) & 31 \\
\hline & 5 & 8.8 & $(0.4)$ & 13.2 & (o.1) & 32 \\
\hline & 6 & 1.6 & (0.2) & 6.2 & (o.1) & 34 \\
\hline & 7 & 19.5 & (o.8) & 25.6 & (o.1) & 28 \\
\hline & Total & 82.2 & $(0.5)$ & 89.1 & (o.1) & 31 \\
\hline Intensive & o & 21.8 & (o.6) & 16.5 & (o.1) & 4 \\
\hline & 1 & 21.4 & (o.6) & 14.6 & (o.1) & 1 \\
\hline & 2 & 18.7 & (o.6) & 16.5 & (o.1) & 7 \\
\hline & 3 & 13.1 & $(0.4)$ & $15 \cdot 3$ & (o.1) & 29 \\
\hline & 4 & 6.7 & $(0.3)$ & 10.8 & (o.1) & 32 \\
\hline & 5 & 6.4 & $(0.4)$ & 9.9 & (o.1) & 33 \\
\hline & 6 & 2.2 & (0.2) & 5.6 & (o.1) & 34 \\
\hline & 7 & 9.8 & $(0.5)$ & 10.7 & (o.1) & 20 \\
\hline & Total & 78.2 & $(0.4)$ & 83.5 & (o.1) & 31 \\
\hline
\end{tabular}

As per table 5. Turkey ranks fourth in the OECD country ranking at this point. The rate of non-participants of any moderate physical activity outside of school is high. Turkey ranks fourth in the OECD country ranking. Turkey fell below the OECD average and ranked 31st.

Table-6: The weekly average of physical activities performed outside of school by gender

\begin{tabular}{llllll}
\hline & & \multicolumn{2}{c}{ Turkey } & \multicolumn{2}{c}{ OECD Av. } \\
& & Ort. & SH & Ort. & SH \\
\hline Moderate physical & Total & 3.98 & -0.05 & 4.88 & -0.01 \\
activity outside school for & Male & 4.05 & -0.06 & 5.00 & -0.01 \\
at least 6o minutes a day & Female & 3.91 & -0.06 & 4.75 & -0.01 \\
Intensive physical activity & Total & 3.38 & -0.04 & 3.95 & -0.01 \\
outside of school for & Male & 3.91 & -0.05 & 4.38 & -0.01 \\
at least 20 minutes a day & Female & 2.86 & -0.04 & 3.51 & -0.01 \\
\hline
\end{tabular}

According to Table 6 . regarding gender variables. the difference between male and female students in Turkey (o.o6) is wider than the OECD average (o.o1).

As per Table-7, students in the upper quartile of the country's socio-economic profile do more sports after school.

Table-7: Students distribution doing sports after school according to gender and socio-economic profile

\begin{tabular}{llllll}
\hline Profile & Group & \multicolumn{2}{c}{ Turkey } & \multicolumn{2}{c}{ OECD Av. } \\
& & $\%$ & SH & $\%$ & SH \\
\hline Gender & Male & 76.4 & $(1.0)$ & 72.3 & $($ o.2) \\
& Female & 50.7 & $(1.3)$ & 60.1 & $($ o.2) \\
& Gender Diff. & 25.6 & $(1.6)$ & 12.2 & $($ o.2) \\
Socio-economic & Lower quarter & 56.9 & $(1.7)$ & 61.0 & $($ o.3) \\
profiles of students & 2nd quarter & 62.1 & $(1.5)$ & 65.3 & $($ o.3) \\
and schools* & 3rd quarter & 66.1 & $(1.7)$ & 67.7 & $($ o.2) \\
& Upper quarter & 68.5 & $(1.7)$ & 70.5 & $($ o.2) \\
& Upper-Lower & 11.6 & $(2.3)$ & 9.5 & $($ o.3) \\
& quarter difference & & &
\end{tabular}

* The socio-economic profile was measured by the PISA economic, social and cultural status index.

Table-8: Life satisfaction levels of students according to their participation in PE classes at school

\begin{tabular}{|c|c|c|c|c|c|c|c|}
\hline & \multicolumn{2}{|l|}{ A } & \multicolumn{2}{|l|}{ B } & \multicolumn{2}{|l|}{ C } & D \\
\hline & Av. & $\mathrm{SH}$ & Av. & $\mathrm{SH}$ & Av. & $\mathrm{SH}$ & Diff. SH \\
\hline Türkiye & 6.17 & (o.o8) & 6.08 & (0.07) & -0.09 & (0.08) & $-0.09(0.08)$ \\
\hline OECD Ort. & 7.23 & (0.02) & $7 \cdot 35$ & (0.01) & 0.13 & (0.02) & (0.02) \\
\hline
\end{tabular}

$\mathrm{A}=$ Students attending PE lesson for two days or less at school

$\mathrm{B}=$ Students attending $\mathrm{PE}$ classes for three days or more at school

$\mathrm{C}=$ Without calculating the socioeconomic prof iles of students \& schools

$\mathrm{D}=$ Socio-economic prof iles of students and schools by calculation

* The socioeconomic prof ile was measured by the PISA economic. social. and cultural status index.

According to table 8, it is seen that the socio-economic profiles of students and schools do not change their life satisfaction according to the duration of students' participation in physical education classes.

\section{Discussion \& Conclusion:}

In this study, in which the appearance of physical education and sports in the country according to the PISA-2015 student research of the OECD was examined, the following results were obtained: It has been observed that the participation rate of 15 -year-old students in weekly physical education classes at school in Turkey $(95.0 \%)$ is above the OECD average (93.1\%). Among the 34 OECD countries (Italy did not report data), Japan ranked first, and Turkey ranked 25th in the rate of physical education participation. Considered the socio-economic and cultural development levels of the countries, it can be said that Turkey is in a good position among OECD countries.

There is a small $5 \%$ difference in students' participation in weekly physical education classes at school between Japan and Turkey, which ranked first. It can be thought that this difference is since, in the Turkey sample, Ambient Science (2020) http://www.caves.res.in/ 
students who are most prepared for the PISA exams have taken the academic level. When we look at Turkey's distribution results in PISA-2015 science literacy by school types, it is seen that science high schools rank first in terms of average scores, followed by social sciences high schools and Anatolian high schools. Secondary schools take last place in this ranking (MEB, 2016). Students who are in the upper quartile of PISA-2015 science performance scores in Turkey participate less in physical education classes than the OECD average also supports this result. It has been observed that the average of students doing exercise or sports before school and those doing exercise or sports both before and after school is above the OECD average, while the average of students who exercise or sports only after school is below the OECD average. In terms of gender, it is observed that the average of male participants before and after school and female participants only before going to school are above the OECD average, while female participants after school remain below the OECD average. $82.2 \%$ of the students in the country stated that they do moderate physical activity on some days of the week, and $78.2 \%$ stated that they do intensive physical activity. The OECD average is $89.1 \%$ and $83.5 \%$, and it has been determined that Turkey is below the OECD average. It was determined that the average of the day of the students who performed at least 60 minutes of moderate and at least 20 minutes of intensive physical activity outside of school in Turkey remained below the OECD average, and the difference between male and female students in Turkey by gender was more comprehensive than the OECD average. However, this situation is not unique to Turkey. In some international studies, the findings of 15 -year-old students participating in moderate and severe physical activities showed that boys and socio-economically advantageous students engage in more physical activities than girls and socio-economically disadvantaged students (Polat \& Madra, 2018).

In studies conducted in the context of gender, while showing the fact that the physical education course environment cannot be handled independently of gender relations (Koca \& Demirhan, 2005), it has been revealed that participation in sports, traditional features of various sports are related to gender suitability between perceptions and beliefs of women /men (In: Kavasoglu \& Yasar, 2016).

According to the research titled "Gender-Based Achievement Difference in Turkey in the Light of PISA and TIMSS 2015" conducted by the Education Reform Initiative (ERG), Female students in Turkey are unsuccessful than male students in transforming characteristics such as selfconfidence, sense of belonging to the school, motivation, and loving learning into success (Polat \& Madra, 2018). While the ratio of male students doing sports after school in Turkey is above the OECD average, it is observed that the proportion of female participants after school is below the
OECD average. The difference between male and female participants after school in Turkey is higher against female students than the OECD average. It has been observed that students in the upper quartile of their socio-economic profile do more sports after school in Turkey. Dolu (2018), in his research on the mathematical analysis of equality of opportunity in education in Turkey through the 2015 PISA results, found that the variables affecting Turkey's educational performance are socio-economic status, gender, class repetition status, school type, and region, which are caused by students and schools. In the study, it was found that there are significant differences in achievement, especially between regions and school types, and the socio-economic status factor of the student, which prevents equal opportunity in education, has a limited effect on achievement.

It has been observed that the life satisfaction of the students who attended less physical education classes in Turkey and the students who attended physical education classes more than the OECD country average were higher, and the socio-economic profiles of the students according to their participation in physical education classes did not change the life satisfaction of the students. On the other hand, considering the socio-economic profiles of participants before and after school, it is seen that the difference between the life satisfaction of students in Turkey is above the OECD average. In Turkey, the difference in life satisfaction of students doing moderate physical activity three days a week and those not doing any physical activity is above the OECD score difference, while the difference in life satisfaction of participants in intensive physical activity and non-participants is below the OECD scoredifference.

Studies show that individuals' overall life satisfaction can be affected by many aspects such as health status, economic status, education level, environmental factors, social relations, and personal security (OECD, 2013). For this reason, there will inevitably be differences in the life satisfaction of individuals between countries. The factors that limit students in participating in physical activities related to physical education and sports inside and outside of school (academic success expectation, economic reasons, lack of facilities, regional demographic culture, etc.) can also be reflected in students' life satisfaction. On the other hand, it was emphasized that the education system's quality is related to economic indicators, and differences between countries are caused by the budget allocated for education and demographic structure (Acar, 2012). It is seen that there is a linear relationship between student performances in PISA exams and investments made by countries in education (In:Aydin et al., 2018).

Consequently, some countries' relative welfare allows them to spend more on education, while some countries find themselves restricted to a lower national income. 
Therefore, it is vital to consider the countries' economic indicators when comparing education systems' performance between countries (Aytekin \& Tertemiz, 2018). Studies show a positive relationship between students' high welfare and life satisfaction and the opposite relationship with common welfare (Pollard \& Lee, 2003). However, despite all these conditions, physical education and sports in the education system have a broader meaning and importance in individuals' lives than their relationship with academic success. For example, physical education class offers students many natural opportunities to develop collaborative social skills and behavior. Education politicians, practitioners, students, and their families need to acknowledge that $\mathrm{PE}$ is not competing with academic classes but complementary (Bailey, 2006). In this study, according to the OECD's PISA-2015 student research, the general view of Turkey's indicators related to physical education and sports within the OECD was tried to be described, and the relationship between academic success and PISA was not discussed. At this point, new research can bedone from different perspectives.

\section{References:}

Acar, T. (2012): According to the PISA 2009 results of Turkey's position among OECD member and candidate countries. Edu. Sci. Theory Prac., 12(4):2561-2572.

Atik, I. (2017): According to the 2015 Program for International Student Assessment results-vocational education in Turkey.. . High. Edu. Sci., 7(3):484-493.

Aydin, A., Selvitopu, A. \& Kaya, M. (2018): Investments in education and PISA 2015 results: A comparative review. Elem. Edu. Online, 17(3):1283-1301.

Aytekin, G.K. \& Tertemiz, N.I. (2018): The results of PISA (20032015) examining the scope of the education system and the economic indicators Turkey and South Korea. L. Ahi Evran Univer. Kirsehir Fac. Edu., 19(1):103-128.

Azarkan, E. (2014): An evaluation of the legal measures that can be applied in case of individual fundamental rights violations by international organizations. Dicle Univers. Fac. Law I., 19(3031):45-6o.

Bailey, R. (2006): Physical education and sport in schools: A review of benef its and outcomes. J. School Health, 76(8):397-401.

Currie, C., Zanotti, C., Morgan, A., Currie, D., de Looze, M., Roberts, C., et al. (2012): Social determinants of health and well-being among young people. Copenhagen: World Health Organization Regional Off ice for Europe.

Dolu, A. (2018): 2015 Mathematical analysis of equal opportunities in education in Turkey through PISA results. L. Süleyman Demirel Univer. Fac. Eco. Admin. Sci., 23(3):923-935.

Dös, I. \& Atalmis, E.H. (2016): Evaluation of PISA exam results according to OECD data. Abant Izzet Baysal Univer. J. Edu. Fac., 16(2): 432-450.

Duran, C. (2019): Physical education and sports teachers in Turkey and Finland to compare the rear section of the course and entrance examination (M.Sc.). Bartin University, Institute of Educational Sciences, Bartin.
Erdem, K.B. \& Tat, O. (2019): An international comparison on the efficiency of using educational resources. Theor Pract. Edu., 15(2):153-170.

Erdogan, E. \& Güvendir, M.A. (2019): The relationship between students' socioeconomic characteristics and reading skills in an international student assessment program. Eskisehir Osmangazi Univers. L. Soc. Sci., 20:493-523.

Iseri, A. (2019): Turkey international PISA competencies and curriculum gains. Mersin Univers. J. Edu. Fac., 15(2):392-41.

Karasar, N. (2014): Scientific Research Method (26. Edition.). Ankara: Nobel Publications.

Kavasoglu, I. \& Yasar, M. (2016): Athletes outside of gender norms. L. SportSci., 27(3):118-132.

Kiliçaslan, H. \& Yavuz, H. (2019): Relationship with education spending in Turkey PISA results. Information, 21(2):296-319.

Koca, C. \& Demirhan, G. (2005): Gender reproduction in physical education and sports. L. Sport Sci., 16(4):200-228

MEB (2016): International student assessment program PISA-2015 national report. General Directorate of Measurement, Evaluation and Examination Services, Ankara. https://odsgm.meb.gov.tr/test/analizler/docs/PISA/PISA2015_Ulusal _Rapor.pdf Date of access: 05.08.2020

MEB (2020): What is PISA ?, http://pisa.meb.gov.tr/?page_id=18, Access date: 05.08 .2020

OECD (2017): PISA 2015 results (Volume III): Students' well-being. P I S A, O E C D P u b l i s h i n g, P a r i s, https://doi.org/10.1787/9789264273856-en.

OECD (2013): OECD Guidelines on measuring subjective well-being, OECD Publishing, Paris, http://dx.doi.org/10.1787/9789264191655en.

Polat, E. \& Madra, A. (2018): PISA 2015 ve TIMSS 2015 In light of the success of gender-based differences in Turkey. Education Reform Initiative and Aydin Dogan Foundation. http: //www.egitimreformu girisimi.org/wp-content/ uploads / 2018/o2 / PisaTimss Information Note TR. 16.02.18.rev1_.pdf, Access date: 28.08.2020

Pollard, E.L. \& Lee, P.D. (2003): Child well-being: A systematic review of the literatüre. Soc. Indic. Res., 61(1):59-78.

Özkan, U.B. (2020): The effect of students' participation in extracurricular activities on their academic success according to PISA-2015 data. Inönü Univers. J. Edu. Fac., 21(1):254-269.

Suna, H.E., Tanberkan, H. \& Özer, M. (2020): Change according to the type of school years and the literacy skills of students in Turkey: student performance on PISA applications. J. Measur. Eval. Edu. Psychol., 11(1):76-97.

Saban, I.H. (2019). Mathematics textbooks, examination of questions in the field of learning algebra according to PISA mathematics proficiency levels (Master's Thesis), Hacettepe University, Inst. Educational Sciences, Ankara.

Topçu, A. \& Durak, H.Y. (2019): Evaluation of teacher STEM education according to PISA results. VIth International Eurasian Educational Research Congress. 19-22 June, Ankara University, proceedings book, 75-8o.

Yildirim, K. (2012). The main factors determining the quality of education in Turkey according to the PISA 2006 data. Tur. J. Edu. $\underline{\text { Sci., } 10(2): 229-255}$ 